\title{
Purification and Characterization of a Thermostable $\beta$-Mannanase from Bacillus subtilis BE-91: Potential Application in Inflammatory Diseases
}

\author{
Lifeng Cheng, Shengwen Duan, Xiangyuan Feng, Ke Zheng, Qi Yang, and Zhengchu Liu \\ Institute of Bast Fiber Crops, Chinese Academy of Agricultural Sciences, Changsha, Hunan 410205, China \\ Correspondence should be addressed to Zhengchu Liu; liuzhengchu@caas.cn
}

Received 30 July 2016; Revised 14 September 2016; Accepted 19 September 2016

Academic Editor: Kai Wang

Copyright (c) 2016 Lifeng Cheng et al. This is an open access article distributed under the Creative Commons Attribution License, which permits unrestricted use, distribution, and reproduction in any medium, provided the original work is properly cited.

$\beta$-mannanase has shown compelling biological functions because of its regulatory roles in metabolism, inflammation, and oxidation. This study separated and purified the $\beta$-mannanase from Bacillus subtilis BE-91, which is a powerful hemicellulosedegrading bacterium using a "two-step" method comprising ultrafiltration and gel chromatography. The purified $\beta$-mannanase (about $28.2 \mathrm{kDa}$ ) showed high specific activity $\left(79,859.2 \mathrm{IU} / \mathrm{mg}\right.$ ). The optimum temperature and $\mathrm{pH}$ were $65^{\circ} \mathrm{C}$ and 6.0 , respectively. Moreover, the enzyme was highly stable at temperatures up to $70^{\circ} \mathrm{C}$ and $\mathrm{pH} 4.5-7.0$. The $\beta$-mannanase activity was significantly enhanced in the presence of $\mathrm{Mn}^{2+}, \mathrm{Cu}^{2+}, \mathrm{Zn}^{2+}, \mathrm{Ca}^{2+}, \mathrm{Mg}^{2+}$, and $\mathrm{Al}^{3+}$ and strongly inhibited by $\mathrm{Ba}^{2+}$ and $\mathrm{Pb}^{2+} . K_{m}$ and $V_{\max }$ values for locust bean gum were $7.14 \mathrm{mg} / \mathrm{mL}$ and $107.5 \mu \mathrm{mol} / \mathrm{min} / \mathrm{mL}$ versus $1.749 \mathrm{mg} / \mathrm{mL}$ and $33.45 \mu \mathrm{mol} / \mathrm{min} / \mathrm{mL}$ for Konjac glucomannan, respectively. Therefore, $\beta$-mannanase purified by this work shows stability at high temperatures and in weakly acidic or neutral environments. Based on such data, the $\beta$-mannanase will have potential applications as a dietary supplement in treatment of inflammatory processes.

\section{Introduction}

Mannan consists of a series of complex polysaccharides, which are found in the cell wall of marine algae [1]. The backbone is comprised of $\beta$-1,4-linked mannose residues. Konjac glucomannan is a randomly arranged polymer of $\beta$ 1,4-linked glucose and mannose residues at ratio of $1.0: 1.6$. Both the backbones of mannan and Konjac are modified by $\alpha$-1,6-linked galactosyl residues to form galactomannan and galactoglucomannan, respectively [2].

$\beta$-mannanase (EC 3.2.1.78) is a hemicellulase that attacks the internal glycosidic bonds of mannan backbone to release the condensed $\beta$-1,4-manno-oligosaccharides [3]. $\beta$ mannanases are widely applied in pulp and paper processing [4], feed [5], food [6], pharmaceutical [7], oil, and textile industries [8] to randomly hydrolyze the $\beta-1,4$ mannopyranoside linkage in mannan, galactomannan, glucomannan, and galactoglucomannan.

$\beta$-mannanase is widely produced by bacteria $[9,10]$, actinomycetes [11], fungi [12], plants, and animals [13]. Among them, $\beta$-mannanase from bacteria is wildely used because of numerous advantages, including extracellular secretion, economic production and purification, and novel characteristics, such as tolerance to heat and alkaline conditions [14].

Although multiple $\beta$-mannanase-producing bacteria have been reported $[15,16]$, they are far from the diverse industry needs. Currently, acidic and alkaline $\beta$-mannanase has been proposed to meet the industrial demands [17]. However, the requirements of high energy in production and the environmental impact limit their development. Neutral and weakly acidic $\beta$-mannanase with lower energy for production has attracted considerable interest over the past few years; however, it has rarely been characterized. It is clarified that $\beta$-mannanase with high activity in short fermentation time confers lower costs during the production procedures. Therefore, the exploitation of strains producing high $\beta$-mannanases activity is valuable and profitable. In current study, we isolated and preserved a powerful hemicellulose-degrading bacterium (BE-91). Then we explored 
the efficient purification process and characterized the enzymatic properties of its $\beta$-mannanase.

\section{Materials and Methods}

2.1. Microorganism, Media, and Fermentation Conditions. B. subtilis BE-91, a strain used for herbaceous fiber extraction, was identified and preserved by the Institute of Bast Fiber Crops, Chinese Academy of Agricultural Science (Changsha, Hunan, China). B. subtilis BE-91 was cultured in Petri dish containing $0.5 \%$ yeast extract, $1 \% \mathrm{NaCl}, 0.5 \%$ Konjac glucomannan, $1 \%$ bacto tryptone, $0.05 \%$ trypan blue, and $1.5 \%$ agar. The seed medium was mainly composed of $0.1 \%$ glucose, $0.4 \%$ Konjac glucomannan, $0.3 \%$ beef extract, $0.2 \%$ yeast extract, $0.5 \%$ peptone, and $0.5 \% \mathrm{NaCl}$. The fermentation medium primarily consisted of $0.2 \%$ yeast extract, $0.7 \%$ Konjac glucomannan, $0.5 \%$ peptone, $0.3 \%$ beef extract, and $0.5 \% \mathrm{NaCl}$. B. subtilis BE-91 was first activated in the seed medium at $35 \pm 1^{\circ} \mathrm{C}$ for $5.5 \mathrm{~h}$. Subsequently, the suspension was serially diluted, spread onto Petri dishes, and incubated at $35 \pm 1^{\circ} \mathrm{C}$ for $18 \mathrm{~h}$. The single colony exhibiting the largest hydrolytic halo was transferred into an Erlenmeyer flask with the seed medium and cultured at $35 \pm 1^{\circ} \mathrm{C}$ for $6 \mathrm{~h}$ at $180 \mathrm{rpm}$. Consequently, $2 \%$ culture was inoculated in the fermentation medium and cultured for $6 \mathrm{~h}$ at $35 \pm 1^{\circ} \mathrm{C}$ at $180 \mathrm{rpm}$ [18].

2.2. Classification of Strain BE-91. The 16S rDNA of strain BE-91 was PCR amplified from genomic DNA using the Bacterial Identification PCR Kit (TaKaRa, Japan). The obtained 16S rDNA was sequenced by the ABI 3730XL 96capillary DNA analyzer. The primers were as follows: P1 $5^{\prime}$-AGAGTTTGATCMTGGCTCAG-3' and P2 $5^{\prime}$-TACGGYTACCTTGTTACGACTT- $3^{\prime}$. The resulting sequence aligned closely with the related standard sequences of other bacteria retrieved from GenBank. Neighbor-joining clusters were constructed by Mega 6.0 [19].

2.3. Enzymatic Assays. $\beta$-mannanase activity was estimated by initiating the reaction at $65^{\circ} \mathrm{C}$ for $10 \mathrm{~min}$ in $0.05 \mathrm{~mol} / \mathrm{L}$ citric acid $/ 0.1 \mathrm{~mol} / \mathrm{L} \mathrm{Na}_{2} \mathrm{HPO}_{4}$ buffer ( $\mathrm{pH} 6.0$ ) with $0.2 \%$ (w/v) Konjac glucomannan as substrate. The amounts of reducing sugar in the reaction were quantified based on a standard curve generated with mannose using the 3,5-dinitrosalicylic acid (DNS) method. One unit (IU) of $\beta$-mannanase activity was defined as the amount of protein producing $1 \mu \mathrm{mol} / \mathrm{L}$ of reducing sugar per minute (e.g., mannose) under standard conditions [20].

2.4. Purification of $\beta$-Mannanase. The bacterial $\beta$-mannanase was purified using a two-step process involving ultrafiltration (Sartorius, Germany) and gel filtration. The fermentation liquid was fractionated orderly by $100 \mathrm{kDa}, 50 \mathrm{kDa}$, and $5 \mathrm{kDa}$ membrane thresholds. The solution filtered with $5 \mathrm{kDa}<\mathrm{MW}$ $<50 \mathrm{kDa}$ was further purified on a Sephadex G-100 gel column $(\Phi 1.6 \mathrm{~cm} \times 100 \mathrm{~cm}$, Pharmacia). The eluate was obtained at a rate of $0.5 \mathrm{~mL} / \mathrm{min}$ and collected in $5 \mathrm{~mL}$ fractions. $\beta$ mannanase activity was determined by the DNS method, whereas the protein was quantified by the Coomassie brilliant blue staining against bovine serum albumin (BSA) standard [21].

2.5. The Determination of Apparent Molecular Weight. The molecular mass of the $\beta$-mannanase was determined by SDS-PAGE (Bio-Rad, USA), with 3\% stacking gel and $12 \%$ separating gel [22]. The protein bands were stained with $0.01 \%$ Coomassie brilliant blue R-250 and destained with a water-methanol-acetic acid (9:9:2) solvent. Zymogram analysis was performed by the method of Chanhan [17]. The molecular weight of $\beta$-mannanase was derived from the relative mobility of molecular weight markers resolved simultaneously.

2.6. The Effect of Temperature on the Activity and Stability of $\beta$-Mannanase. The activity of $\beta$-mannanase was assayed at a range of temperatures between 50 and $70^{\circ} \mathrm{C}$ in $0.05 \mathrm{~mol} / \mathrm{L}$ citric acid- $0.1 \mathrm{~mol} / \mathrm{L} \mathrm{Na}_{2} \mathrm{HPO}_{4}$ buffer at $\mathrm{pH}$ 6.0. The thermostability was assessed by preincubating the enzyme, without a substrate, at different temperatures varying over $20-80^{\circ} \mathrm{C}$ for $30 \mathrm{~min}$. The residual activity was promptly measured by the DNS method. The $\beta$-mannanase activity was considered to be $100 \%$ when preincubated at $4^{\circ} \mathrm{C}$.

2.7. The Effect of $p H$ on the Activity and Stability of $\beta$ Mannanase. $\beta$-mannanase activity was evaluated by incubating the purified enzyme at different $\mathrm{pH}$ conditions ranging from 4.0 to 8.0 in $0.05 \mathrm{~mol} / \mathrm{L}$ citric acid- $0.1 \mathrm{~mol} / \mathrm{L} \mathrm{Na}_{2} \mathrm{HPO}_{4}$ buffer at $4^{\circ} \mathrm{C}$. The stability at a particular $\mathrm{pH}$ was tested by preincubating the purified enzyme, without a substrate, for $30 \mathrm{~min}$ in various $0.05 \mathrm{~mol} / \mathrm{L}$ citric acid- $0.1 \mathrm{~mol} / \mathrm{L} \mathrm{Na}_{2} \mathrm{HPO}_{4}$ buffers at $\mathrm{pH} 3.0-8.5$ at $4^{\circ} \mathrm{C}$. The residual $\beta$-mannanase activity was immediately measured after treatment by the DNS procedure.

2.8. The Effect of Metal Ions on the Activity of $\beta$-Mannanase. In order to examine the effects of metal ions on the activity of $\beta$-mannanase, the enzyme was incubated for $30 \mathrm{~min}$ at $4^{\circ} \mathrm{C}$ in the presence of various $1.0 \mathrm{mmol} / \mathrm{L}$ metal ions, $\mathrm{CaCl}_{2} \cdot 2 \mathrm{H}_{2} \mathrm{O}$, $\mathrm{ZnCl}_{2}, \mathrm{FeCl}_{3}, \mathrm{PbCl}_{2} \cdot 2 \mathrm{H}_{2} \mathrm{O}, \mathrm{MnCl}_{2} \cdot 4 \mathrm{H}_{2} \mathrm{O}, \mathrm{MgCl}_{2} \cdot 6 \mathrm{H}_{2} \mathrm{O}, \mathrm{KCl}$, $\mathrm{CuCl}_{2} \cdot 2 \mathrm{H}_{2} \mathrm{O}, \mathrm{AlCl}_{3}, \mathrm{BaCl}_{2}$, and $\mathrm{NH}_{4} \mathrm{Cl}$. The residual $\beta$ mannanase activity was measured at a specific condition and that of the treatment in the absence of additives as a control.

2.9. Substrate Specificity and Kinetic Parameters. Various glycans, such as Konjac glucomannan [23], locust bean gum from Ceatonia siliqua seeds (Sigma, G0753), carob galactomannan (Megazyme, P-GALML), guar galactomannan (Megazyme, P-GGMMV), ivory nut mannan (Megazyme, P-MANIV), 1,4-beta-D-mannan (Megazyme, P-MANCB), wheat arabinoxylan (Megazyme, P-120601a), beechwood xylan (Megazyme, P-141101a), and carboxymethyl cellulose (Megazyme, P-CMC4M) were examined. In brief, 0.2\% (w/v) glycans were incubated with $\beta$-mannanase at $65^{\circ} \mathrm{C}$ for $10 \mathrm{~min}$ in $0.05 \mathrm{~mol} / \mathrm{L}$ citric acid- $0.1 \mathrm{~mol} / \mathrm{L} \mathrm{Na}_{2} \mathrm{HPO}_{4}$ buffer at $\mathrm{pH}$ 6.0 , and the reducing sugars were measured by DNS. The Michaelis-Menten kinetic parameters, $V_{\max }$ and $K_{m}$, were calculated for $\beta$-mannanase. The assays of the purified enzyme were carried out by the standard DNS procedure, as described 
TABLE 1: $\beta$-mannanase activities of five bacteria.

\begin{tabular}{lcc}
\hline Bacterium number & Activity $(\mathrm{IU} / \mathrm{mL})^{\mathrm{a}}$ & ${\text { Specific activity }(\mathrm{IU} / \mathrm{mg})^{\mathrm{a}}}^{\mathrm{a}}$ \\
\hline BE-23 & 0 & 0 \\
$\mathrm{BE}-78$ & $191.5 \pm 4.5$ & $879.8 \pm 13.2$ \\
$\mathrm{BE}-46$ & $83.2 \pm 2.1$ & $311.6 \pm 9.4$ \\
$\mathrm{BE}-83$ & $70.7 \pm 1.6$ & $119.7 \pm 25.5$ \\
BE-91 & $273.7 \pm 6.5$ & $2,319.2 \pm 26.3$ \\
\hline
\end{tabular}

${ }^{\mathrm{a}}$ Data are mean $\pm \mathrm{SD}, n=3$.

above, using $1-5 \mathrm{mg} / \mathrm{mL}$ locust bean gum and $0.5-2.5 \mathrm{mg} / \mathrm{mL}$ Konjac glucomannan as substrates. The kinetic constants were determined from the Michaelis-Menten equation by directly inputting the initial rates from Lineweaver-Burk plots or the nonlinear regression [24].

2.10. Statistical Analysis. Each $\beta$-mannanase activity experiment was performed in triplicate and expressed as mean \pm SD (standard deviation). The statistical analyses were performed with SPSS 15.0 (SPSS Inc., Chicago IL, USA). One-way or two-way analysis of variance (ANOVA) was used to compare various treatment groups.

\section{Results and Discussion}

3.1. Screening of the High $\beta$-Mannanase Activity Producing Strain. Four bacteria were stochastically selected for the $\beta$-mannanase activity assay. Figure 1 exhibited the halos produced on the screening plate. Table 1 summarized the $\beta$-mannanase activity of the four bacteria (strain BE-23 without $\beta$-mannanase activity was used as a negative control). Strain BE-91 fermented for $9 \mathrm{~h}$ exhibited the highest activity, up to $273.7 \mathrm{IU} / \mathrm{mL}$. Wild-type B. subtilis MA139 yielded a maximum $\beta$-mannanase activity of $170 \mathrm{IU} / \mathrm{mL}$ after 3 days of fermentation, and the maximum enzyme activity of $B$. subtilis TJ-102 was $205.3 \mathrm{IU} / \mathrm{mL}$ at $38 \mathrm{~h}[25,26]$. Notably, BE91 secreted $\beta$-mannanase with higher activity in shorter time.

3.2. Classification of $B$. subtilis BE-91. The $1,508 \mathrm{bp}$ sequence of $16 \mathrm{~S}$ rDNA of strain BE-91 was analyzed by a phylogenic tree (Figure 2). The homology between BE-91 16S rDNA (gi 260159552) and B. subtilis $16 \mathrm{~S}$ rDNA (gi 530330588 and gi 341831474 ) was $99 \%$. It was confirmed that the similarity of $B$. subtilis type strains about $16 \mathrm{~S}$ rRNA gene sequence is higher than $98 \%[27,28]$. We also obtained $\geq 98 \%$ similarity to $16 \mathrm{~S}$ rRNA gene sequences of $B$. subtilis isolates.

3.3. Isolation and Purification of $\beta$-Mannanase. $2,000 \mathrm{~mL}$ of fermentation liquor was purified by ultrafiltration and chromatography. Specific activity, recovery, and multiple purifications at each step were summarized in Table 2 . The recovery of $\beta$-mannanase in B. subtilis BE-91 exceeded $66.0 \%$; multiple purifications achieved 32.9-fold pure $\beta$-mannanase activity, and the specific activity of the purified enzyme reached $79,859.2 \mathrm{IU} / \mathrm{mg}$. The purified $\beta$-mannanase was shown to be homogeneous judged by SDS-PAGE analysis (Figure 3). Compared with the previous separation and purification

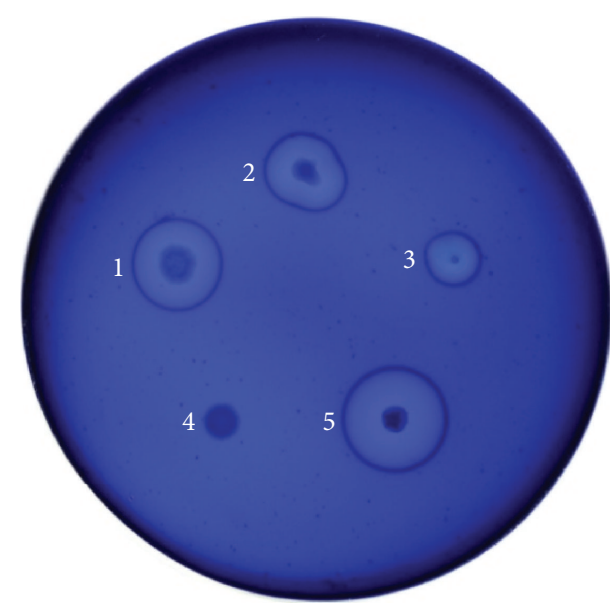

FIGURE 1: Clear halos produced by control and active colonies with $\beta$-mannanase activity 1, BE-78; 2, BE-46; 3, BE-83; 4, BE-23 (negative control); 5, BE-91.

methods $[29,30]$, the two-step method has the advantages of high efficiency, high yield, and easy operation.

3.4. Apparent Molecular Weight of $\beta$-Mannanase. The apparent molecular weight of $\beta$-mannanase was $28.2 \mathrm{kDa}$ (Figure 3), lower than those of the most known $\beta$-mannanases from Bacillus spp. (Bacillus licheniformis THCM 3.1, $40 \mathrm{kDa}$; . subtilis WY34, $39.6 \mathrm{kDa}$; B. subtilis $\mathrm{Z}-2,38 \mathrm{kDa}$; Bacillus circulans CGMCC1554, $32 \mathrm{kDa}$ ) [28, 31-34]. Similarly, the molecular weights of $\beta$-mannanases from Penicillium occitanis Po16 and Bacillus halodurans PPKS-2 were 22 and $18 \mathrm{kDa}$, respectively $[30,31]$. Due to low molecular weights, these enzymes may rapidly penetrate the lignocellulose systems and depolymerize the mannans more efficiently [35].

3.5. Optimal Temperature and Thermostability of $\beta$-Mannanase. The purified $\beta$-mannanase was maximally active at $65^{\circ} \mathrm{C}$ (Figure 4) and remained more than $80 \%$ active at $70^{\circ} \mathrm{C}$ (Figure 5). Compared with the optimal temperatures obtained for other $\beta$-mannanases $\left(40^{\circ} \mathrm{C}\right.$ for Penicillium occitanis Pol6; $50^{\circ} \mathrm{C}$ for both Bacillus circulans TN-31 and $B$. subtilis $\mathrm{B} 36 ; 60^{\circ} \mathrm{C}$ for Paenibacillus sp. DZ3) [29, 31, 36], $\beta$ mannanase of BE-91 showed a pronounced activity at higher temperatures. As compared to the thermostability of the $\beta$ mannanase from wild-type B. subtilis BCC41051 $\left(60^{\circ} \mathrm{C}\right.$ for $30 \mathrm{~min}$ ) [37], this $\beta$-mannanase retains $80 \%$ residual activity after incubation at $20-70^{\circ} \mathrm{C}$ for $30 \mathrm{~min}$, indicating enhanced thermostability.

3.6. Optimal $p H$ and Stability of $\beta$-Mannanase. The optimal $\mathrm{pH}$ and the stability of BE-91 $\beta$-mannanase were measured at various $\mathrm{pHs}$. The optimum enzyme activity was obtained at pH 6.0 (Figure 6), and more than $80 \%$ maximal activity was retained at $\mathrm{pH}$ 4.5-7.0 (Figure 7). Interestingly, the optimal $\mathrm{pH}$ of BE-91 $\beta$-mannanase was the same as that of $B$. subtilis MA139 ( $\mathrm{pH}$ 6.0), an enzyme that can potentially be used 
TABLE 2: Purification of $\beta$-mannanase by ultrafiltration and gel chromatography.

\begin{tabular}{lccccc}
\hline Purification step & Total activity (IU) & Total protein $(\mathrm{mg})$ & Specific activity (IU/mg) & Recovery (\%) & Purification multiple (fold) \\
\hline Fermentation liquor & $429,650.8$ & 176.7 & $2,431.4$ & 100 & 1 \\
Ultrafiltration & $328,317.4$ & 8.6 & $38,070.2$ & 76.4 & 15.6 \\
Gel chromatography & $283,500.2$ & 3.6 & $79,859.2$ & 66.0 & 32.9 \\
\hline
\end{tabular}

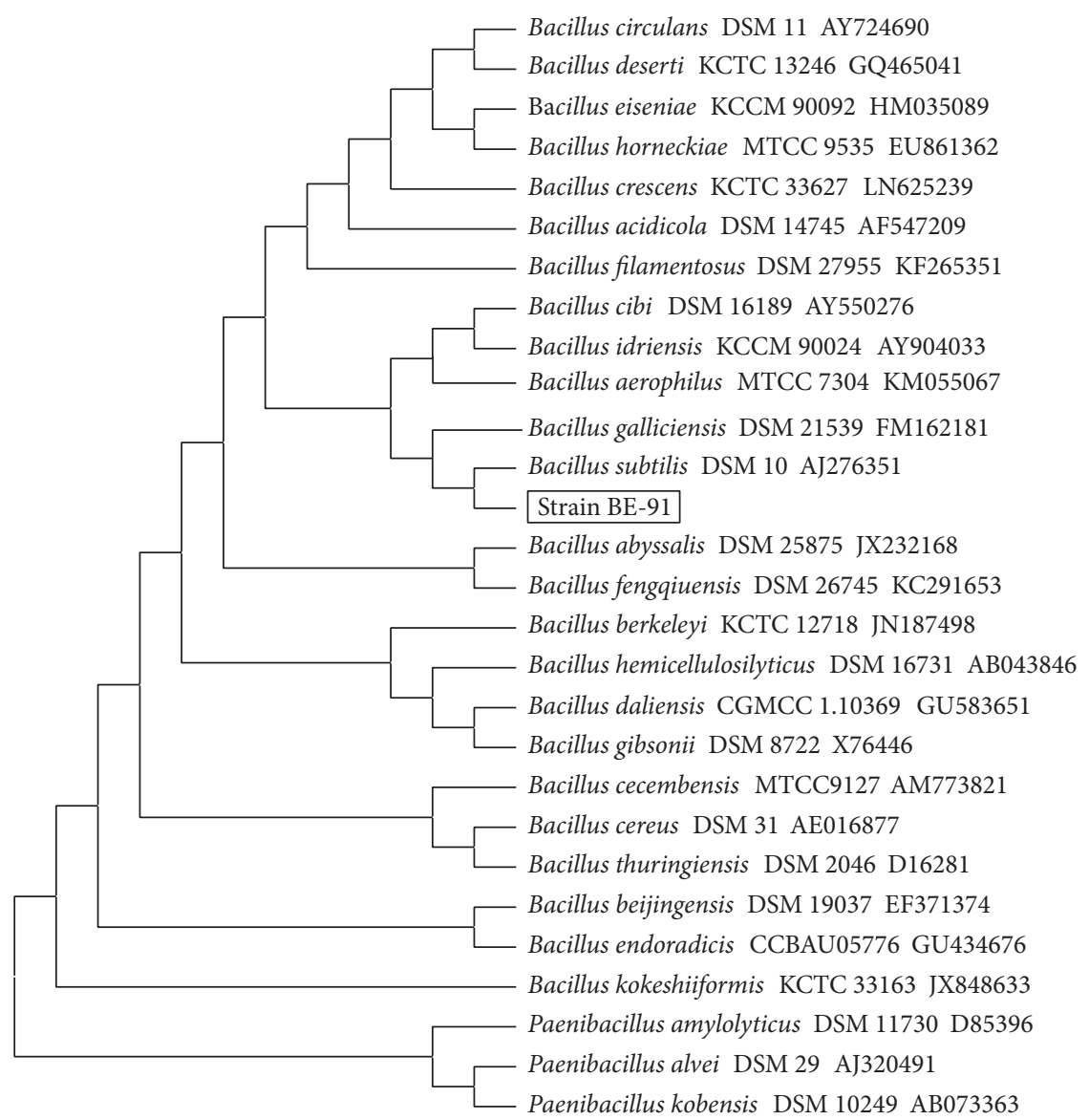

FIGURE 2: Phylogenetic tree based on $16 \mathrm{~S}$ rDNA sequences of strain BE-91 and other bacteria by Mega 6.0 using neighbor-joining analysis with 1000 bootstrap replicates.

as a feed additive for monogastric animals [25]. At $\mathrm{pH}<$ 4.0 , the $\beta$-mannanase activity was negligible, retaining $<80 \%$ of its maximal value obtained after incubation at $\mathrm{pH}>$ $7.5,4^{\circ} \mathrm{C}$ for $30 \mathrm{~min}$. A relatively broad zone of optimum activity was observed. Therefore, BE-91 $\beta$-mannanase can be considered a weakly acidic and neutral enzyme, thereby rendering suitability for animal feed industry [38].

3.7. The Effect of Metal Ions on $\beta$-Mannanase Stability. The effect of a variety of metal ions on $\beta$-mannanase activity was measured (Table 3 ). The highest induction was achieved with $\mathrm{Mn}^{2+}$, which showed $168 \%$ baseline activity, followed by $\mathrm{Al}^{3+}$, $\mathrm{Ca}^{2+}, \mathrm{Cu}^{2+}, \mathrm{Zn}^{2+}, \mathrm{Mg}^{2+}$, and $\mathrm{NH}_{4}{ }^{+}$, respectively. $\mathrm{K}^{+}$and $\mathrm{Fe}^{3+}$ had no obvious effects on $\beta$-mannanase activity in these conditions. $\mathrm{Ba}^{2+}$ and $\mathrm{Pb}^{2+}$ greatly inhibited the enzyme activity to a final rate of $83 \%$ and $74 \%$, respectively. This suggests that BE-91 $\beta$-mannanase should not be contaminated by $\mathrm{Ba}^{2+}$ and $\mathrm{Pb}^{2+}$.
TABLE 3: Effects of different metal ions $(1 \mathrm{mmol} / \mathrm{L})$ on $\beta$-mannanase activity.

\begin{tabular}{lc}
\hline Metal ions & Relative activity $(\%)^{\mathrm{a}}$ \\
\hline Blank & 100 \\
$\mathrm{~K}^{+}$ & $99 \pm 3.2$ \\
$\mathrm{NH}_{4}^{+}$ & $103 \pm 2.7$ \\
$\mathrm{Ca}^{2+}$ & $117 \pm 3.6$ \\
$\mathrm{Zn}^{2+}$ & $115 \pm 2.9$ \\
$\mathrm{Mn}^{2+}$ & $168 \pm 4.5$ \\
$\mathrm{Cu}^{2+}$ & $116 \pm 2.1$ \\
$\mathrm{Mg}^{2+}$ & $107 \pm 2.8$ \\
$\mathrm{Ba}^{2+}$ & $83 \pm 3.1$ \\
$\mathrm{~Pb}^{2+}$ & $74 \pm 2.9$ \\
$\mathrm{Fe}^{3+}$ & $99 \pm 3.6$ \\
$\mathrm{Al}^{3+}$ & $121 \pm 4.3$ \\
\hline
\end{tabular}

${ }^{\mathrm{a}}$ Data are mean $\pm \mathrm{SD}, n=3$. 


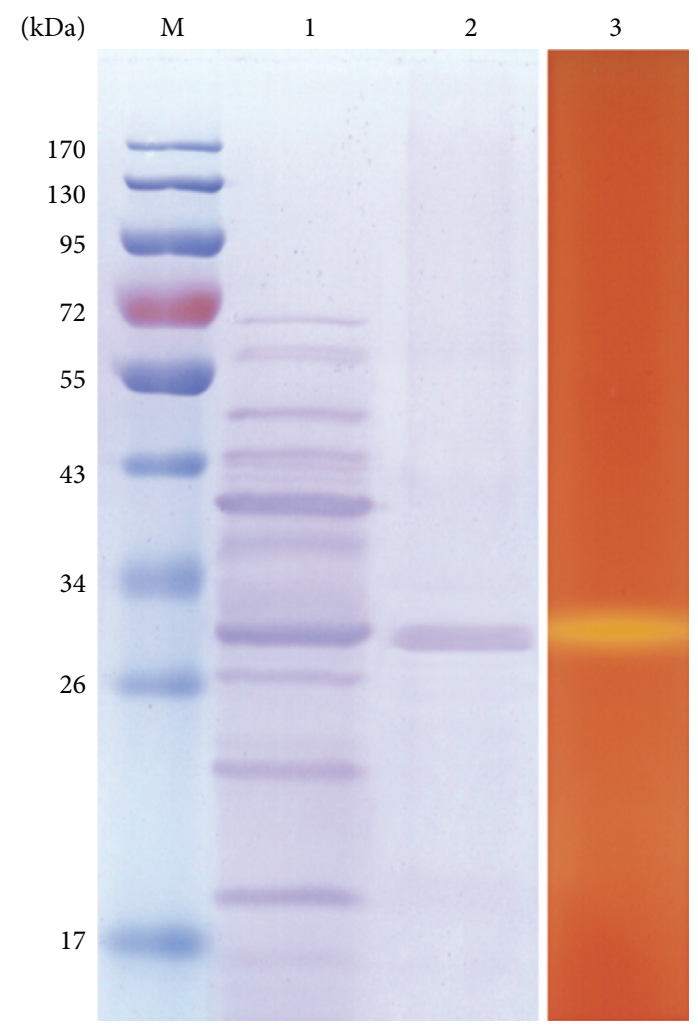

FIGURE 3: SDS-PAGE analysis of $\beta$-mannanase. Lane M: protein molecular weight standard; Lane 1: culture broth; Lane 2: purified $\beta$-mannanase; Lane 3: zymogram of purified $\beta$-mannanase.

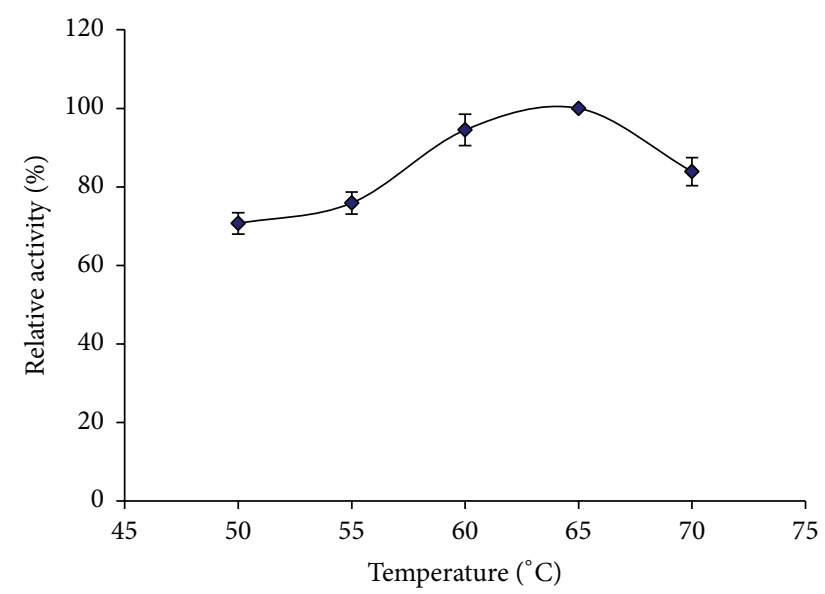

FIGURE 4: Optimum temperature curve of $\beta$-mannanase.

3.8. Kinetic Parameters. The purified enzyme hydrolyzed Konjac glucomannan but only slightly hydrolyzed ivory nut mannan, guar galactomannan, and 1,4-beta-D-mannan. Wheat arabinoxylan, beechwood xylan, and CMC were barely hydrolyzed, as shown in Table 4 . This $\beta$-mannanase exhibited the highest activity with Konjac glucomannan, enriched in glucose units. This finding suggests that $\beta$ mannanase of BE-91 preferentially hydrolyzes the $\beta$-1,4linkage of the glucosylated mannan backbone.

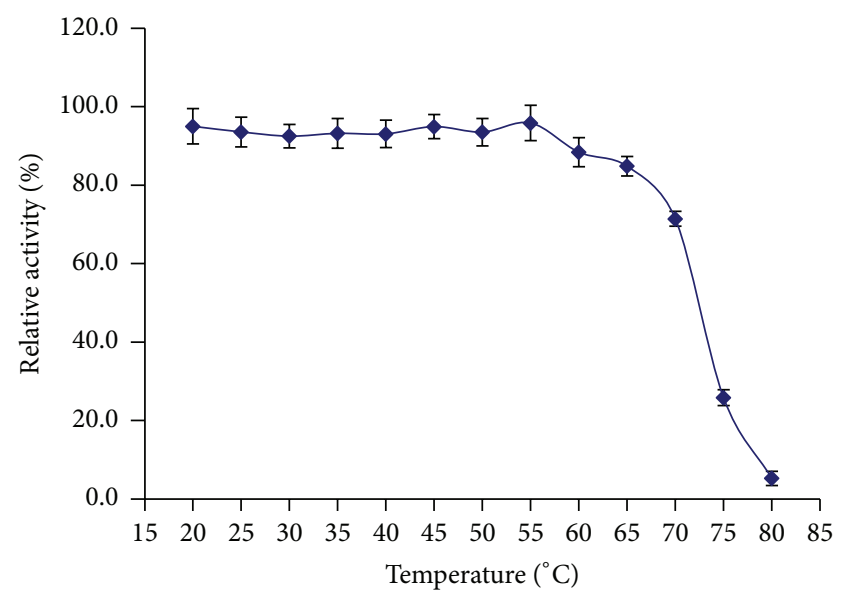

FIgURE 5: Thermal stability curve of $\beta$-mannanase.

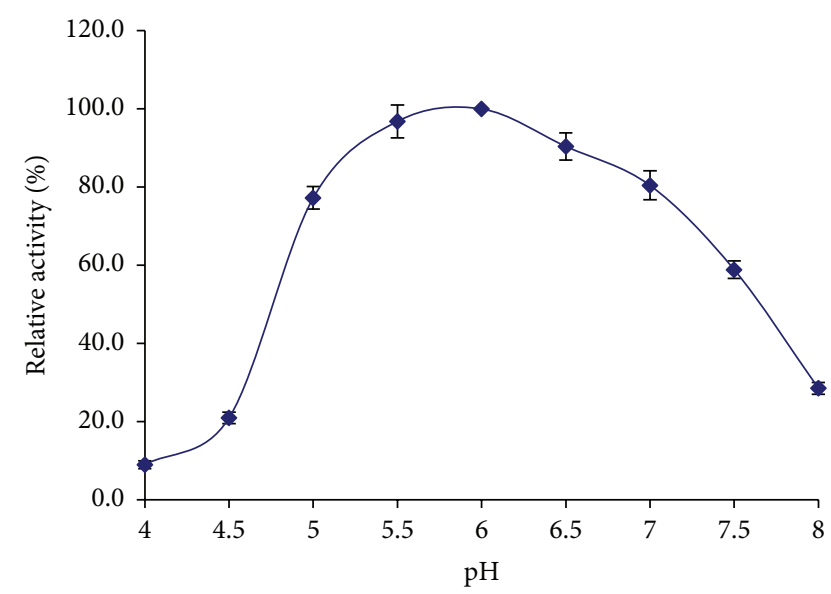

Figure 6: Optimum pH curve of $\beta$-mannanase.

TABLE 4: Hydrolytic activity of the purified enzyme on different polysaccharides.

\begin{tabular}{lc}
\hline Substrate $(0.5 \%, \mathrm{w} / \mathrm{v})$ & Relative activity $(\%)^{\mathrm{a}}$ \\
\hline Konjac glucomannan & 100 \\
Locust bean gum & $88.15 \pm 1.8$ \\
Carob galactomannan & $91.85 \pm 1.7$ \\
Guar galactomannan & $35.70 \pm 0.6$ \\
Ivory nut mannan & $32.74 \pm 0.3$ \\
1,4-Beta-D-mannan & $46.22 \pm 0.4$ \\
Wheat arabinoxylan & 0 \\
Beechwood xylan & 0 \\
Carboxymethyl cellulose & 0 \\
\hline
\end{tabular}

Assays were carried out at $65^{\circ} \mathrm{C}$ at $\mathrm{pH} 6.0$ for $10 \mathrm{~min}$ in $0.05 \mathrm{~mol} / \mathrm{L}$ citric acid$0.1 \mathrm{~mol} / \mathrm{L} \mathrm{Na}_{2} \mathrm{HPO}_{4}$ buffer.

${ }^{\mathrm{a}}$ Data are mean $\pm \mathrm{SD}, n=3$.

$K_{m}$ and $V_{\max }$ values of this $\beta$-mannanase estimated by the Lineweaver-Burk plot were $7.14 \mathrm{mg} / \mathrm{mL}$ and $107.5 \mu \mathrm{mol} /$ $\mathrm{min} / \mathrm{mL}$, respectively, for locust bean gum, versus $1.749 \mathrm{mg} /$ $\mathrm{mL}$ and $33.45 \mu \mathrm{mol} / \mathrm{min} / \mathrm{mL}$ for Konjac glucomannan, 


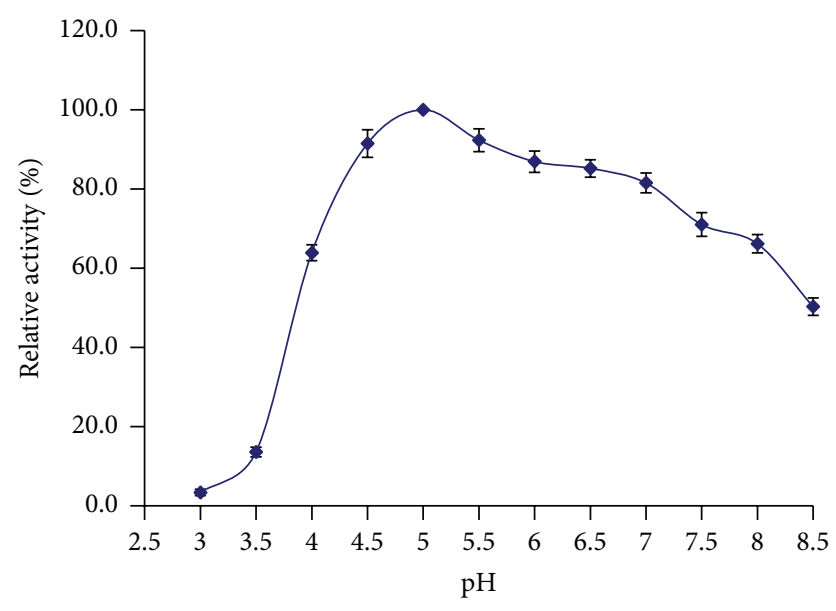

FIgURE 7: $\mathrm{pH}$ stability curve of $\beta$-mannanase.

respectively. These results displayed higher affinity of $\beta$ mannanase towards natural Konjac glucomannan $\left(V_{\max } / K_{m}\right.$, $19.1 \mu \mathrm{mol} / \mathrm{min} / \mathrm{mg})$ than the locust bean gum $\left(V_{\max } / K_{m}\right.$, $15.0 \mu \mathrm{mol} / \mathrm{min} / \mathrm{mg}$ ), similar to the values obtained for Penicillium pinophilum $\mathrm{C} 1$ and Penicillium freii F63, hence constituting it as an adequate candidate in food industry for the production of oligosaccharides $[17,18,39]$.

\section{Conclusion}

B. subtilis bacteria are abundant, moderately stable, and mostly nonpathogenic microorganisms. Our results indicated that B. subtilis BE-91 could be considered a prominent candidate for the production of extracellular $\beta$-mannanase. In addition, this study developed an advanced purification approach, "two-step method," with high efficiency, high yield, and easy operation. Furthermore, the $\beta$-mannanase purified from BE91 was extremely stable at relatively high temperatures and various weak acidic or neutral pHs. Finally, the enzyme showed a higher affinity towards natural Konjac glucomannan, a major functional food material. Therefore, this $\beta$ mannanase, purified and characterized from B. subtilis BE-91 for the first time, is suitable for inflammatory diseases.

\section{Competing Interests}

The authors declare that they have no competing interests.

\section{Acknowledgments}

This study was funded by the Natural Science Foundation of Hunan Province (no. 2016jj3126), National Innovation Engineering of China (no. ASTIP-IBFC08), and the Earmarked Fund for China Modern Agriculture Research System (no. CARS-19).

\section{References}

[1] D. R. Georgianna, M. J. Hannon, M. Marcuschi et al., "Production of recombinant enzymes in the marine alga Dunaliella tertiolecta," Algal Research, vol. 2, no. 1, pp. 2-9, 2013.
[2] G. Gübitz, A. Sachslehner, and D. Haltrich, "Microbial mannanases: substrates, production, and applications," in Glycosyl Hydrolases for Biomass Conversion, chapter 14, pp. 236-262, 2001.

[3] P. S. Chauhan, N. Puri, P. Sharma, and N. Gupta, "Mannanases: microbial sources, production, properties and potential biotechnological applications," Applied Microbiology and Biotechnology, vol. 93, no. 5, pp. 1817-1830, 2012.

[4] X. Pan, J. Zhou, A. Tian et al., "High level expression of a truncated $\beta$-mannanase from alkaliphilic Bacillus sp. N16-5 in Kluyveromyces cicerisporus," Biotechnology Letters, vol. 33, no. 3, pp. 565-570, 2011.

[5] C. Kong, J. H. Lee, and O. Adeola, "Supplementation of $\beta$ mannanase to starter and grower diets for broilers," Canadian Journal of Animal Science, vol. 91, no. 3, pp. 389-397, 2011.

[6] A. Adiguzel, H. Nadaroglu, and G. Adiguzel, "Purification and characterization of $\beta$-mannanase from Bacillus pumilus (M27) and its applications in some fruit juices," Journal of Food Science and Technology, vol. 52, no. 8, pp. 5292-5298, 2015.

[7] W. H. Van Zyl, S. H. Rose, K. Trollope, and J. F. Görgens, "Fungal $\beta$-mannanases: mannan hydrolysis, heterologous production and biotechnological applications," Process Biochemistry, vol. 45, no. 8, pp. 1203-1213, 2010.

[8] A. C. Sehgal and R. M. Kelly, "Strategic selection of hyperthermophilic esterases for resolution of 2-arylpropionic esters," Biotechnology Progress, vol. 19, no. 5, pp. 1410-1416, 2003.

[9] S. Titapoka, S. Keawsompong, D. Haltrich, and S. Nitisinprasert, "Selection and characterization of mannanaseproducing bacteria useful for the formation of prebiotic mannooligosaccharides from copra meal," World Journal of Microbiology and Biotechnology, vol. 24, no. 8, pp. 1425-1433, 2008.

[10] G. Adiguzel, Z. Sonmez, A. Adiguzel, and H. Nadaroglu, "Purification and characterization of a thermostable endo-beta-1,4 mannanase from Weissellaviridescens LB37 and its application in fruit juice clarification," European Food Research and Technology, vol. 242, no. 5, pp. 769-776, 2016.

[11] P. Bhoria, G. Singh, and G. S. Hoondal, "Optimization of mannanase production from Streptomyces sp. PG-08-03 in submerged fermentation," BioResources, vol. 4, no. 3, pp. 1130-1138, 2009.

[12] M. Siti Norita, M. Rosfarizan, and A. B. Ariff, "Evaluation of the activities of concentrated crude mannan-degrading enzymes produced by Aspergillus niger," Malaysian Journal of Microbiology, vol. 6, no. 2, pp. 171-180, 2010.

[13] R. Prakash, S. L. Johnston, H. L. Boldingh et al., "Mannans in tomato fruit are not depolymerized during ripening despite the presence of endo- $\beta$-mannanase," Journal of Plant Physiology, vol. 169, no. 12, pp. 1125-1133, 2012.

[14] H. X. Liu, J. S. Gong, H. Li et al., "Biochemical characterization and cloning of an endo-1,4- $\beta$-mannanase from Bacillus subtilis YH12 with unusually broad substrate profile," Process Biochemistry, vol. 50, no. 5, pp. 712-721, 2015.

[15] H. Mou, F. Zhou, X. Jiang, and Z. Liu, "Production, purification and properties of $\beta$-mannanase from soil Bacterium bacillus circulans m-21," Journal of Food Biochemistry, vol. 35, no. 5, pp. 1451-1460, 2011.

[16] Y. Hakamada, Y. Ohkubo, and S. Ohashi, "Purification and characterization of $\beta$-mannanase from Reinekea sp. KIT-YO10 with transglycosylation activity," Bioscience, Biotechnology and Biochemistry, vol. 78, no. 4, pp. 722-728, 2014.

[17] P. S. Chauhan, P. Sharma, N. Puri, and N. Gupta, "Purification and characterization of an alkali-thermostable $\beta$-mannanase 
from Bacillus nealsonii PN-11 and its application in mannooligosaccharides preparation having prebiotic potential," European Food Research and Technology, vol. 238, no. 6, pp. 927936, 2014.

[18] M. Wang, S. You, S. Zhang et al., "Purification, characterization, and production of $\beta$-mannanase from Bacillus subtilis TJ-102 and its application in gluco-mannooligosaccharides preparation," European Food Research and Technology, vol. 237, no. 3, pp. 399-408, 2013.

[19] K. Tamura, G. Stecher, D. Peterson, A. Filipski, and S. Kumar, "MEGA6: molecular evolutionary genetics analysis version 6.0," Molecular Biology and Evolution, vol. 30, no. 12, pp. 2725-2729, 2013.

[20] T. Akino, N. Nakamura, and K. Horikoshi, "Production of $\beta$ mannosidase and $\beta$-mannanase by an alkalophilic Bacillussp," Applied Microbiology and Biotechnology, vol. 26, no. 4, pp. 323327, 1987.

[21] M. M. Bradford, "A rapid and sensitive method for the quantitation of microgram quantities of protein utilizing the principle of protein-dye binding," Analytical Biochemistry, vol. 72, no. 1-2, pp. 248-254, 1976.

[22] U. K. Laemmli, "Cleavage of structural proteins during the assembly of the head of bacteriophage T4," Nature, vol. 227, no. 5259, pp. 680-685, 1970.

[23] M. Chua, K. Chan, T. J. Hocking, P. A. Williams, C. J. Perry, and T. C. Baldwin, "Methodologies for the extraction and analysis of konjac glucomannan from corms of Amorphophallus konjac K. Koch," Carbohydrate Polymers, vol. 87, no. 3, pp. 2202-2210, 2012.

[24] H. Lineweaver and D. Burk, "The determination of enzyme dissociation constants," Journal of the American Chemical Society, vol. 56, no. 3, pp. 658-666, 1934.

[25] J. Qiao, Z. Rao, B. Dong, and Y. Cao, "Expression of Bacillus subtilis MA139 $\beta$-mannanase in Pichia pastoris and the enzyme characterization," Applied Biochemistry and Biotechnology, vol. 160, no. 5, pp. 1362-1370, 2010.

[26] Y. Wang, P. Shi, H. Luo et al., "Cloning, over-expression and characterization of an alkali-tolerant endo- $\beta$-1,4-mannanase from penicillium freii F63," Journal of Bioscience and Bioengineering, vol. 113, no. 6, pp. 710-714, 2012.

[27] B. K. Dash, M. M. Rahman, and P. K. Sarker, "Molecular identification of a newly isolated Bacillus subtilis BI19 and optimization of production conditions for enhanced production of extracellular amylase," BioMed Research International, vol. 2015, Article ID 859805, 9 pages, 2015.

[28] L. Yang, X. Quan, B. Xue et al., "Isolation and identification of Bacillus subtilis strain YB-05 and its antifungal substances showing antagonism against Gaeumannomyces graminis var. tritici," Biological Control, vol. 85, pp. 52-58, 2015.

[29] M. R. S. Chandra, Y. S. Lee, I. H. Park, Y. Zhou, K. K. Kim, and Y. L. Choi, "Isolation, purification and characterization of a thermostable $\beta$-mannanase from Paenibacillus sp. DZ3," Journal of Applied Biological Chemistry, vol. 54, no. 3, pp. 325-331, 2011.

[30] S. Vijayalaxmi, P. Prakash, S. K. Jayalakshmi, V. H. Mulimani, and K. Sreeramulu, "Production of extremely alkaliphilic, halotolerent, detergent, and thermostable mannanase by the free and immobilized cells of Bacillus halodurans PPKS-2. Purification and characterization," Applied Biochemistry and Biotechnology, vol. 171, no. 2, pp. 382-395, 2013.

[31] M. Blibech, R. E. Ghorbel, I. Fakhfakh et al., "Purification and characterization of a low molecular weight of $\beta$-mannanase from Penicillium occitanis Pol6," Applied Biochemistry and Biotechnology, vol. 160, no. 4, pp. 1227-1240, 2010.

[32] F. Kanjanavas, P. Khawsak, A. Pakpitcharoen et al., "Overexpression and characterization of the alkalophilic, organic solvent-tolerant, and thermotolerant endo-1,4- $\beta$-mannanase from Bacillus licheniformis isolate THCM 3.1," ScienceAsia, vol. 35, no. 1, pp. 17-23, 2009.

[33] Z. Jiang, Y. Wei, D. Li, L. Li, P. Chai, and I. Kusakabe, "High-level production, purification and characterization of a thermostable $\beta$-mannanase from the newly isolated Bacillus subtilis WY34," Carbohydrate Polymers, vol. 66, no. 1, pp. 88-96, 2006.

[34] Q. Zhang, X. Yan, L. Zhang, and W. Tang, "Cloning, sequence analysis and heterologous expression of a beta-mannanase gene from Bacillus subtilis Z-2," Molekuliarnaia Biologiia, vol. 40, no. 3, pp. 418-424, 2006.

[35] R. Martínez-Palou and R. Luque, "Applications of ionic liquids in the removal of contaminants from refinery feedstocks: an industrial perspective," Energy \& Environmental Science, vol. 7, no. 8, pp. 2414-2447, 2014.

[36] Y. Maruyama and T. Nakajima, "The aman6 gene encoding a yeast mannan backbone degrading 1,6- $\alpha$-D-mannanase in Bacillus circulans: cloning, sequence analysis, and expression," Bioscience, Biotechnology and Biochemistry, vol. 64, no. 9, pp. 2018-2020, 2000.

[37] P. Summpunn, S. Chaijan, D. Isarangkul, S. Wiyakrutta, and V. Meevootisom, "Characterization, gene cloning, and heterologous expression of $\beta$-mannanase from a thermophilic Bacillus subtilis," Journal of Microbiology, vol. 49, no. 1, pp. 86-93, 2011.

[38] D. Y. Kim, S. J. Ham, H. J. Lee et al., "Cloning and characterization of a modular GH5 $\beta$-1,4-mannanase with high specific activity from the fibrolytic bacterium Cellulosimicrobium sp. strain HY-13," Bioresource Technology, vol. 102, no. 19, pp. 91859192, 2011.

[39] H. Cai, P. Shi, H. Luo et al., "Acidic $\beta$-mannanase from Penicillium pinophilum $\mathrm{C}$ : Cloning, characterization and assessment of its potential for animal feed application," Journal of Bioscience and Bioengineering, vol. 112, no. 6, pp. 551-557, 2011. 


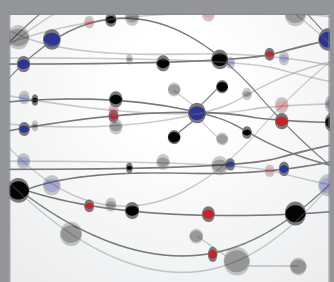

The Scientific World Journal
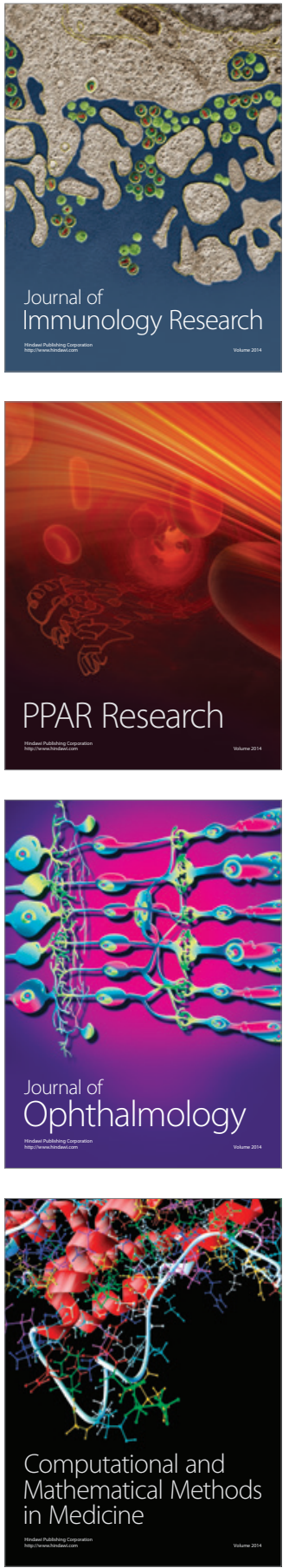

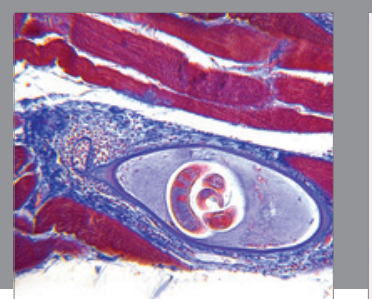

Gastroenterology Research and Practice

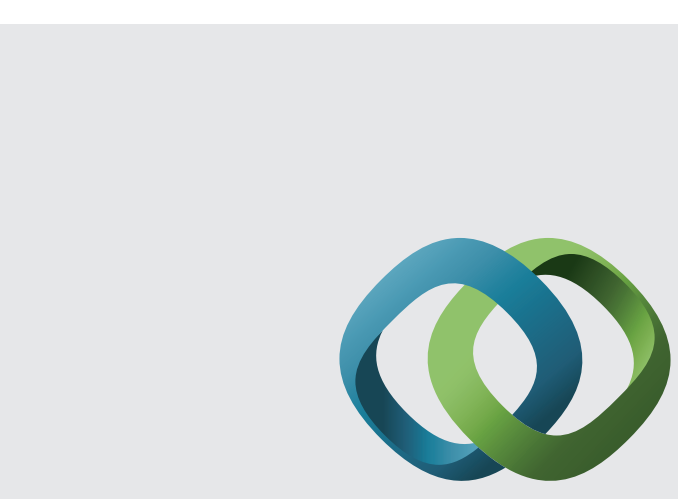

\section{Hindawi}

Submit your manuscripts at

http://www.hindawi.com
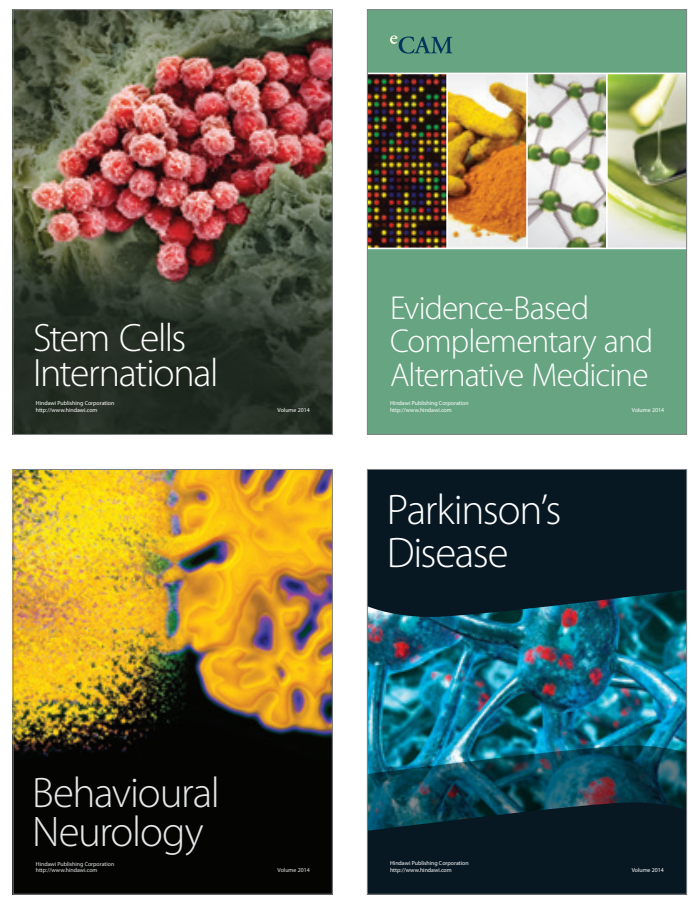
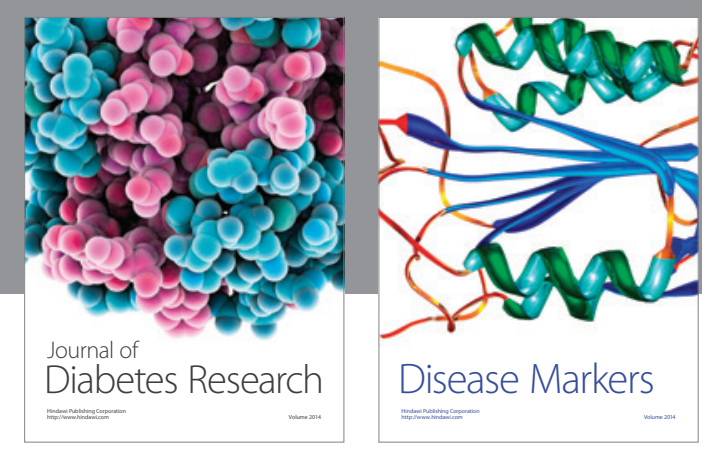

Disease Markers
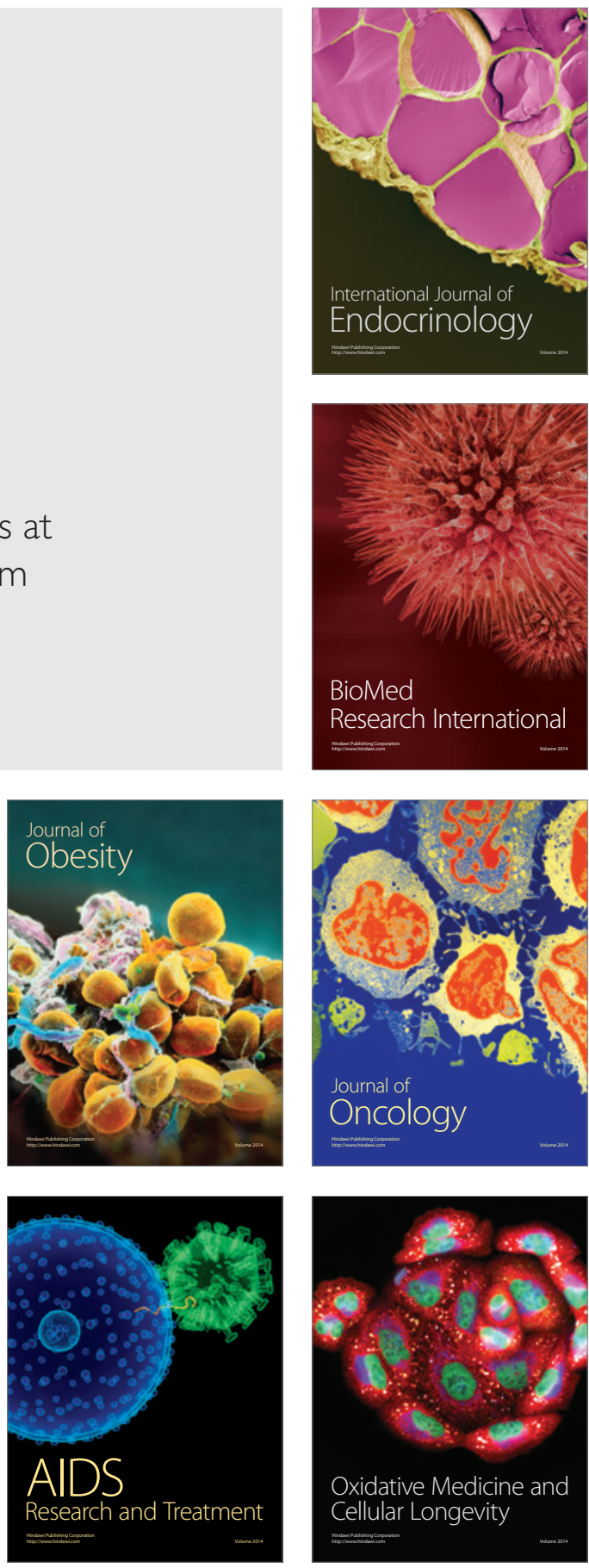